\title{
Control of clay minerals effect in flotation. A review
}

\author{
Hasan Ali Taner ${ }^{1, a}$, and Vildan Onen ${ }^{1}$ \\ ${ }^{1}$ Selcuk University, Department of Mining Engineering, 42075 Konya, Turkey
}

\begin{abstract}
The increased exposure to low grade ores highlights the importance of understanding phyllosilicate gangue mineralogy which consists of common gangue minerals. To improve the flotation performance and ore quality the negative effect of the clay minerals on flotation should be identified. The presence of clay minerals leads to problems, such as changing the froth stability, which are related to swelling behaviour, increase in pulp viscosity, overconsumption of reagents, slime coating and mechanical entrainment. The clay content in the ore is changing from time to time and it is necessary to provide quick solutions to the issues caused by the new ore composition. The objective of this paper is to give an overview how to control the colloidal properties of clay minerals on flotation.
\end{abstract}

\section{Introduction}

Clay minerals are the primary natural materials consisting of fine-grained minerals. Clay minerals are commonly found in many mineralization as gangue minerals and they create problems in all steps of mineral processing. Difficulties in processing of high clay content ores are due to their different and complex structures. The presence of clay minerals leads to problems, such as changing the froth stability, which are related to swelling behaviour, increase in pulp viscosity, overconsumption of reagents, slime coating and mechanical entrainment.

There is a strong relationship between the rheological properties of pulp and flotation performance. The presence of clay minerals can cause adverse effects on the pulp rheology. For instance, montmorillonite type clays due to show a considerable amount of yield stress and their impact on the viscosity of the suspension is very strong. As it is known, that the turbulence in the cell increases the possibility of particle-bubble collisions. The influence of enhanced pulp viscosity also has a detrimental effect on gas dispersion, through districting the turbulent region of flotation cells to a small "turbulent cavern" surrounding the impeller [1-3]. In addition, it is stated that with increase in the pulp viscosity causes increase in froth stability and decrease in detachment of particle from bubble [4].

Clay minerals are composed of cations ( $\mathrm{Si}, \mathrm{Al}, \mathrm{Mg}$ et al.) and anions $(\mathrm{O}$ and $\mathrm{OH})$ and contain broken bonds on their corners, edges and surfaces. Broken edge bonds of clay particles are considered to be particularly positive charged at neutral and acidic $\mathrm{pH}$. Clay surfaces have negative charges while edges are positively charged $[5,6]$. The anisotropic charges on edges and surfaces of clays allow coating the surface of valuable minerals through the electrostatic attraction. Therefore, it causes

${ }^{a}$ Corresponding author: hasanalitaner@selcuk.edu.tr 
inadequate surface hydrophobicity as well reduce the flotation performance and quality of the concentrate [7]. Chemical reagents used in flotation adsorb onto the mineral surfaces. Many clay minerals have a large active surface area supporting adsorption with the ionic and molecular bond structure. Therefore, they also cause more consumption of flotation reagents and increase the operational costs [8].

Flotation is more difficult for fine and ultra-fine particles. One of the challenges in flotation of fine particles is high gangue entrainment. Fine hydrophilic gangue particles easily entrain between bubbles getting into the fine pores and froth layer what results in mechanical entrainment [9]. It is well-known that the froth stability is an important factor determining the flotation performance. Creation and protection of the best froth stability is not a simple process. Clay minerals could prevent adsorption between bubbles and minerals by coating air bubbles [10]. The flotation performance is dependent on ability of the bubbles in collection of hydrophobic particles from pulp. Reduction of capture efficiency of these particles decreases concentration froth stability.

Significant structural differences of clay minerals such as crystallinity, cation exchange capacity, swelling etc. are effective in their behaviour during flotation and these structural differences. The effects can be reduced by:

- removal of clay minerals prior to flotation,

- using of viscosity modifiers,

- removal of clay minerals by washing which are mechanical entrained and not attached to the bubbles,

- operation at low air speed,

- flotation in low pulp densities [11, 12],

- using of special frothers such as cycle-type frothers which are less sensitive during the presence of clay [13],

- using of clay binders as a group of low molecular weight polymers [7, 14].

\section{Control mechanism}

\subsection{Removal of clay minerals prior to flotation}

A common method in plants to reduce an unwanted effect of clay minerals prior to flotation is prevention of fine particles entrance into the flotation process and washing of ores. The plants, that do not apply this method, may face serious difficulties, firstly on flotation circuits, and then thickeners and filters. However, the clay fractions may contain large amount of valuable minerals [15]. This method can be applied if the amount of valuable mineral in the discarded size as a slime is at negligible level. However, in the case of comminution to ultra-fine sizes, a deslime process cannot be considered as a solution because of losses of valuable minerals [16]. Figure 1 shows the effect of quartz particles finer than $10 \mu \mathrm{m}$ on flotation of different iron ores [17].

\subsection{The use of viscosity modifiers}

The rheological behaviour significantly effects the pulp properties, so this indicates the level of either aggregation or interaction of particles. Therefore, it can be used as a useful control parameter in mineral processing. Enrichment of minerals by flotation could be effected by interaction of particles the rheological data present an approach to directly understand this interaction. The rheology has been used to investigate particle-particle interactions in slurries of oxide minerals [18-20], clays and clay minerals [21-24], coal [25, 26], sulphide minerals [27], and even gangue minerals such as talc [28-30].

Accurate measurement of the rheological properties of pulp is rather difficult, because the solid particles tend to settle during measurement. Some researchers have used different methods such as pumping slurry [31], using capillary viscometers [32] or stirring the suspension while measuring with 
Couette-type viscometer [33], to overcome this problem. However, finding a proper practical way to measure the rheology of such slurries still remains a challenge [30]. It was also demonstrated that the recovery of coarse particles increased with the increased medium viscosity controlled by adding certain amount of glycerol [34].

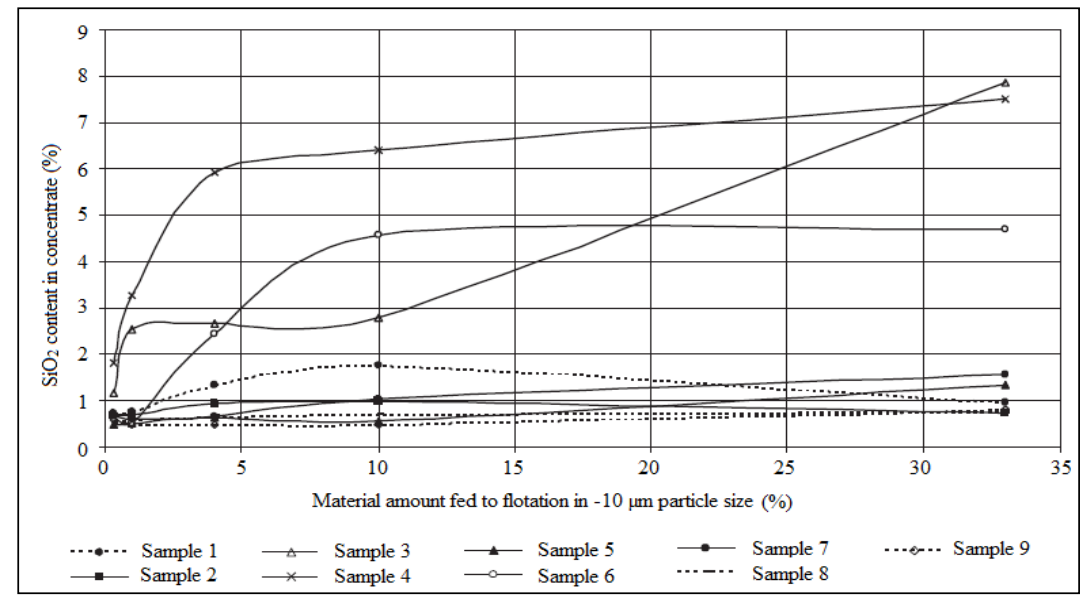

Figure 1. Effect of ultra-fine particles on flotation of different iron ore samples to quartz content in concentrate [17].

\subsection{Removal of clay minerals by washing}

In almost all scientific researches, it is expressed the mechanical entrainment takes place depending on the amount of water obtained from the concentrate. In other words, unless arrival of water in the cell to concentrate is not prevented, mechanical entrainment of fine gangue minerals will not prevent to entrain to the concentrate. One of the ways to reduce the water come from the concentrate is to increase the fluidity of interfacial water between bubbles. The viscosity of the pulp, which has high amount of fine particles, is higher than that of low amount of fine particles, even though they have the same pulp density. In this case, mechanical entrainment can't be reduced adequately neither to provide low air rate nor deeper froth region in order to flow back the water between bubbles to pulp the region. In such cases, giving the washing water from the top of the cell can be referred to a solution.

\subsection{Operation at low air speed}

To flow the water between bubbles into the pulp, waiting of froth for an adequate time could be reduced the amount of water transfer to concentrate. This situation is possible by either decreasing the froth flow rate or increasing froth depth, only. However, one of the most important drawbacks of either increasing froth depth or decreasing froth flow rate is to increase probability of bubble coalescence in the froth region.

The most important variable is the air flow rate supplied to the cell. It is expected to decrease mechanical entrainment by two important reasons if the low air rate is used. The first reason is decreasing mechanical entrainment as a result of reducing the froth flow rate because of relative reduction of the froth volume in the froth region. Secondly, when the air flow rate decreases, naturally, stirring in pulp decreases and the flow regime in the cell has lower Reynold number, so the decrease in fluctuation occurs in the pulp-froth interface, and then mechanical entrainment decreases. Therefore, the air flow rate and froth depth are considerable control variables in flotation plants [16]. 


\subsection{The use of depressants and clay binders}

In flotation, sodium silicate $\left(\mathrm{Na}_{2} \mathrm{SiO}_{3}\right)$, called water glass, has fairly common use to depress silicate and carbonate minerals present as gangue minerals. Also, it is an effective dispersant. Sodium silicate that chemical composition could vary, acts as either a distributor or a depressant depending on the $\mathrm{SiO}_{2} / \mathrm{Na}_{2} \mathrm{O}$ ratio, also known as a module number [16].

Aggregation of fine and surface coating of coarse particles are not desired during the flotation. Dispersion is the condition of particles being apart enough from each other in the pulp. Prior to flotation to prevent aggregation of fine and slime coating particles, that is dispersion, one of the polyphosphate compounds can be used. Sodium hexametaphosphate, commercially known as Calgon prevents aggregation and slime coating by forming complex ions with $\mathrm{Ca}^{2+}$ and $\mathrm{Mg}^{2+}$ ions so minimizing effects in thinning the electrical double layer around these ions. With these effects, they also prevent similar metal ions to activate minerals other than a target [16].

The clay binder plays an important role as a slime depressant that agglomerates clay particles to increase the size, lower the surface area, clean bubble and particle surfaces and reduce adsorption of surfactants (Fig. 2). Selection of appropriate binders and optimizing the dosage is important for the flotation performance and selectivity. Two main adsorption mechanisms of clay binder are dipoledipole interaction and strong hydrogen bond. Because of amphiprotic characteristic and multiple binding and chelating sites, binding can be very selective [35]. As is shown in Fig. 2, when clay minerals are present as individual particles, they adsorb a large amount of reagents due to their large surface area (clay minerals are being adsorbed on both ore particles and air bubbles). The clay will also be adsorbed on the coal particles and bubble surfaces as a result of electrostatic interactions, what is referred as slime coating. Clay binders were used to agglomerate clay minerals and depress them and also to reduce their surface area and expose fresh coal particle surface and fresh bubble surface.

An experimental laboratory study was conducted to evaluate the performance of clay binders in the fine coal flotation process [14]. According to the results a clean coal product of $8-8.5 \%$ ash was produced from a feed of more than $19 \%$ ash with $97-98 \%$ combustible recovery. Binders significantly enhanced flotation selectivity, reducing clean coal ash from $8-8.5 \%$ to $7-7.5 \%$. Also, flotation performance increased $15-30 \%$ based on the high rotation speed. Phosphate flotation using clay binders was studied and a significant increase about $5 \%$ in phosphate recovery and $1.5 \%$ in grade was achieved [36].

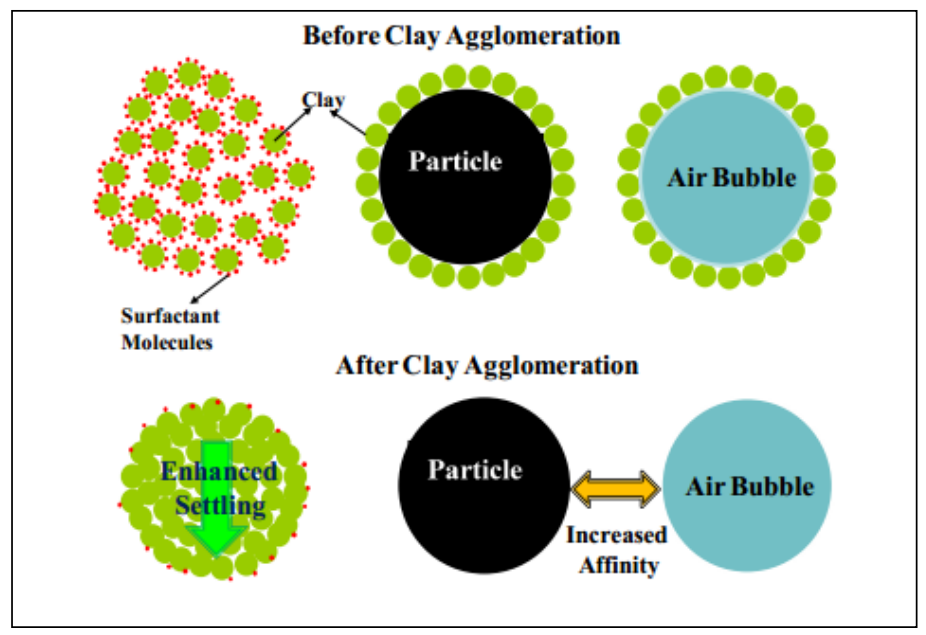

Figure 2. Illustration of how clay agglomeration improves flotation performance by removing slime coating from the mineral particle and bubble surface and increasing clay particle size [14]. 


\section{Conclusions}

Clay minerals constitute challenges by decreasing flotation and creating a complex tailing in flotation. Improvement of the flotation performance and product quality require ensuring the effect of clay minerals and understanding of this mechanism.

By taking into account solutions mentioned above to overcome the negative effects of clays, it can be considered to have detailed data related to solve the clay problem in plants. However, clays are still one of the major problems in period from comminution to dewatering stage in plants while enriching high clay content ores. This case can be stated that due to undetailed investigation of effect to mechanism of complex structure of clays and structural differences. Nowadays, this issue is more importance due to necessity of enrichment the low-grade ores.

\section{References}

1. C. W. Bakker, C. J. Meyer and D.A. Deglon, Miner. Eng., 22(11), 944 (2009)

2. N.Z.P. Shabalala, M. Harris, L.S. Leal Filho, D.A. Deglon, Miner. Eng., 24(13), 1448 (2011)

3. E. Forbes, K.J. Davey and L. Smith, Miner. Eng. 56, 136 (2014)

4. D. Xu, I. Ametov and S.R. Grano, Int. J, Miner. Process., 101(1-4), 50 (2011)

5. Y. Akın, M.S. Celik, End. Hammaddeler Semp. (İzmir, 1995)

6. A. Evcin, T. Kavas, 5.Endüstriyel Hammaddeler Semp. (İzmir, 2004)

7. M. Zhang and Y. Peng, Miner. Eng., 70, 8 (2015)

8. W.J. Oats, O. Ozdemir and A.V. Nguyen, Miner. Eng., 23:413-419 (2010)

9. H. Ozer, Yüksek Lisans Tezi, (Süleyman Demirel Üniv. Fen Bilimleri Ens,. Isparta, 2007)

10. W.W. Wen and S.C. Sun, Trans. of AIME, 262:174 (1977)

11. S.M. Bulatovic, Miner. Eng., 10(9), 895 (1997)

12. T. Ozgen, Yüksek Lisans Tezi, (Hacettepe Üniv. Fen Bilimleri Ens., Ankara, 2014)

13. S.M. Bulatovic, H. of Flot. R.: Chem., Th. and Prac.: Flot. of Sulp. O., (Elsevier: Boston, 2007)

14. D. Tao, P.G. Dopico, J. Hines and D. Kennedy, Pro. of the Int. Coal P. C.,(USA, 2010)

15. İ. Bayraktar, 14. Cevher Hazırlama Kongresi, Inv. papers, Kuşadası, (2014)

16. E.C. Cilek, Mineral flotasyonu, SDU. Müh.-Mim. Fak., Kitap Yayın, 59 (2006)

17. N.P. Lima, M.Sc thesis, In Portuguese (2001)

18. M.L. Taylor, G.E. Morris and R.S.C. Smart, J. Colloid Interface Sci., 262, 81 (2003)

19. F.J. Rubio-Hernández, M.F. Ayúcar-Rubio, J. F. Velázquez-Navarro and F. J. Galindo-Rosales, J. Colloid Interface Sci., 298, 967 (2006)

20. S. Farrokhpay, G.E. Morris, D. Fornasiero and P. Self, Powder Tech., 202(1-3), 143 (2010)

21. P. Mpofu, J. Addai-Mensah and J. Ralston, Int. J. Miner. Process., 71, 247 (2003)

22. A. J. McFarlane, J. Addai-Mensah and K. Bremmell, Miner. Eng., 18(12), 1173 (2005)

23. A. Nosrati, J. Addai-Mensah and W. Skinner, Chem. Eng., Sci. 66, 119 (2011)

24. Z. A. Zhou, O. Worku, L.X. Wang, Z. Xu and J.H. Masliyah, CIM J., 3(1), 54 (2012)

25. R. W. Lai, L.G. Mc Mahan, A.G. Richardson and S.H. Chiang, Advances in Coal and Min. Proc. Using Flot., Soc. for Mining, Met. and Exp. Inc. (Littleton, Collorado, 1989)

26. H. Dincer, F. Boylu, A.A. Sirkeci and G. Atesok, Int. J. Miner. Process., 70, 41 (2003)

27. T. H. Muster and C.A. Prestidge, Miner. Eng., 8(12), 1541 (1995)

28. G.E. Morris, D. Fornasiero and J. Ralston, Int. J. Miner. Process., 67, 211 (2002)

29. E. Burdukova, D.J. Bradshaw and J. S. Laskowski, Can. Metall. Q., 46, 273 (2007)

30. S. Farrokhpay, Miner. Eng., 36, 272 (2012)

31. C. Boudrias-Chapleau, C. Bazin and D. Cotnoir, In: Pawlik, M. (Ed.), Proc. of 8th UBC-McGillUA Inter. Sym. on the Fund. of Min. Proc.: Rheology and Proc. of Fine Partic., 43 (2011)

32. S.K. Kawatra and A.K. Bakshi, Int. J. Miner. Process., 47, 275 (1996)

33. J. Gustafsson, M. Toivakka and K.K. Koskinen, Annu. Tr. Nord. Rhe. Soc., 13, 277 (2005)

34. D. Xu, I. Ametov and S. R. Grano, Miner. Eng., 39, 89 (2012) 
35. L. Zhang, MSc thesis., (University of Kentucky, 2013)

36. J. Kou, X. Guangyang, T. Daniel, G.D. Pablo, H. John and K. Dennis, Phosphate flotation enhancement using clay binder (2012) 